\title{
Cuora flavomarginata (Gray 1863) - Yellow-Margined Box Turtle
}

\author{
Hidetoshi Ota ${ }^{1}$, Yuichirou Yasukawa ${ }^{2}$, Jinzhong Fu ${ }^{3}$, and Tien-Hsi Chen $^{4}$ \\ ${ }^{1}$ Tropical Biosphere Research Center, University of the Ryukyus, \\ Nishihara-cho, Okinawa 903-0213, Japan [ota@sci.u-ryukyu.ac.jp]; \\ ${ }^{2}$ District Office Okinawa, Takada Reptiles and Wildlife Research Institute, \\ 1-15-3 Teruya, Okinawa City, Okinawa 904-0011, Japan [guau_yasukawa@ybb.ne.jp]; \\ ${ }^{3}$ Department of Integrative Biology, University of Guelph, Guelph, Ontario N1G 2W1, Canada [jfu@uoguelph.ca]; \\ ${ }^{4}$ Ching Kuo Institute of Management and Health, Keelung, Taiwan [cuora.flavo@msa.hinet.net]
}

Summary. - The yellow-margined box turtle, Cuora flavomarginata, (Family Geoemydidae), is a small species (carapace length to $190 \mathrm{~mm}$ ), that occurs in eastern and southern continental China, Taiwan, and the southern Ryukyus of Japan. The species is mainly terrestrial and is found in and around primary and dense secondary forests, feeding on both small animals and plant materials, such as insects, earthworms, and berries. Clutch size usually ranges from one to four, and the female tends to be larger in body mass than the male, sometimes exceeding $1000 \mathrm{~g}$. The yellow-margined box turtle is threatened by deforestation in its natural habitat, and large numbers have been exploited for food and traditional Chinese medicine and also exported from continental China for pets. This exploitation has caused the decline of many populations of this turtle. Capture and trade in Japanese and Taiwanese populations are currently regulated by national laws, but habitat destruction progresses in both countries. There is thus urgency that areas of habitat be set aside and protected. In order to devise effective conservation measures, it is also important to undertake research on life history and population status of the species; information on these aspects is insufficient, especially for the non-Taiwanese populations.

Distribution. - China (Continental), China (Taiwan), Japan. Distributed on Ishigakijima and Iriomotejima islands of the southern Ryukyu Archipelago (Japan), Taiwan, and Minjiang, Fuchun, and Yangtze River drainages of eastern continental China.

Synonymy. - Cistoclemmys flavomarginata Gray 1863, Cuora flavomarginata, Terrapene flavomarginata, Cyclemys flavomarginata, Geoemyda flavomarginata, Cyclemys flavomarginata sinensis Hsü 1930, Terrapene culturalia Yeh 1961.

SubSPECIES. - Two currently recognized by us: Cuora flavomarginata flavomarginata (Common Yellow-Margined Box Turtle) (synonymy: Cyclemys flavomarginata flavomarginata, Cuora flavomarginataflavomarginata,Cistoclemmys flavomarginata flavomarginata,Cyclemys flavomarginata sinensis, Cuora flavomarginata sinensis, Cistoclemmys flavomarginata sinensis) and Cuora flavomarginata evelynae (Ryukyu Yellow-Margined Box Turtle) (synonymy: Cuora evelynae Ernst and Lovich 1990, Cistoclemmys flavomarginata evelynae).

STATUS. - IUCN 2009 Red List: Endangered (ENA1cd+2cd) (assessed 2000); CITES: Appendix II (as Cuora spp.).

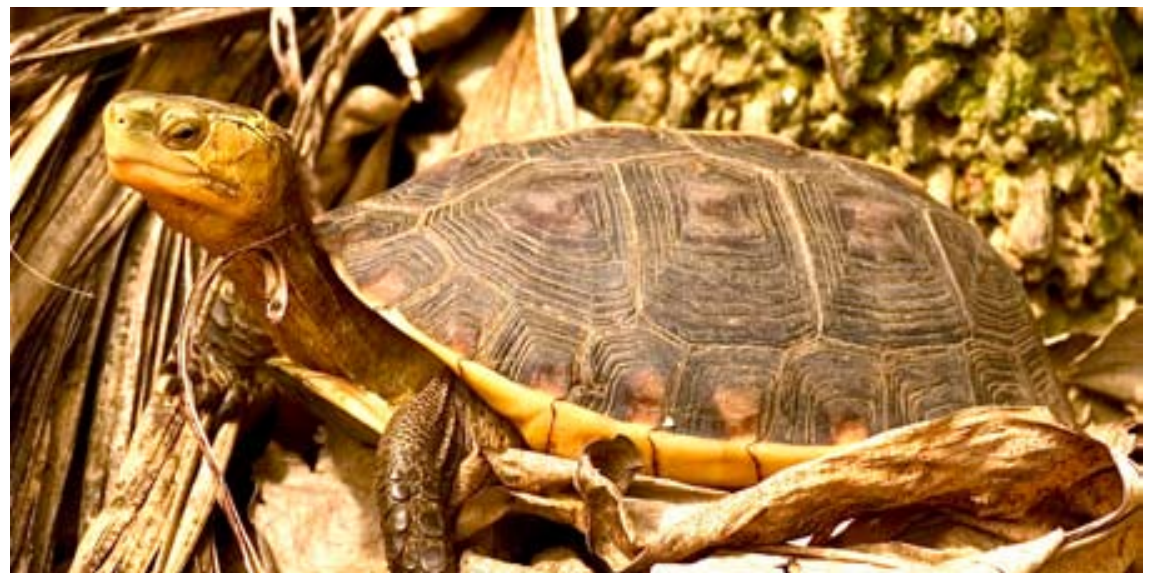

Figure 1. Cuora flavomarginata flavomarginata, adult female from Nantou, central Taiwan. Photo by Tien-Hsi Chen. 

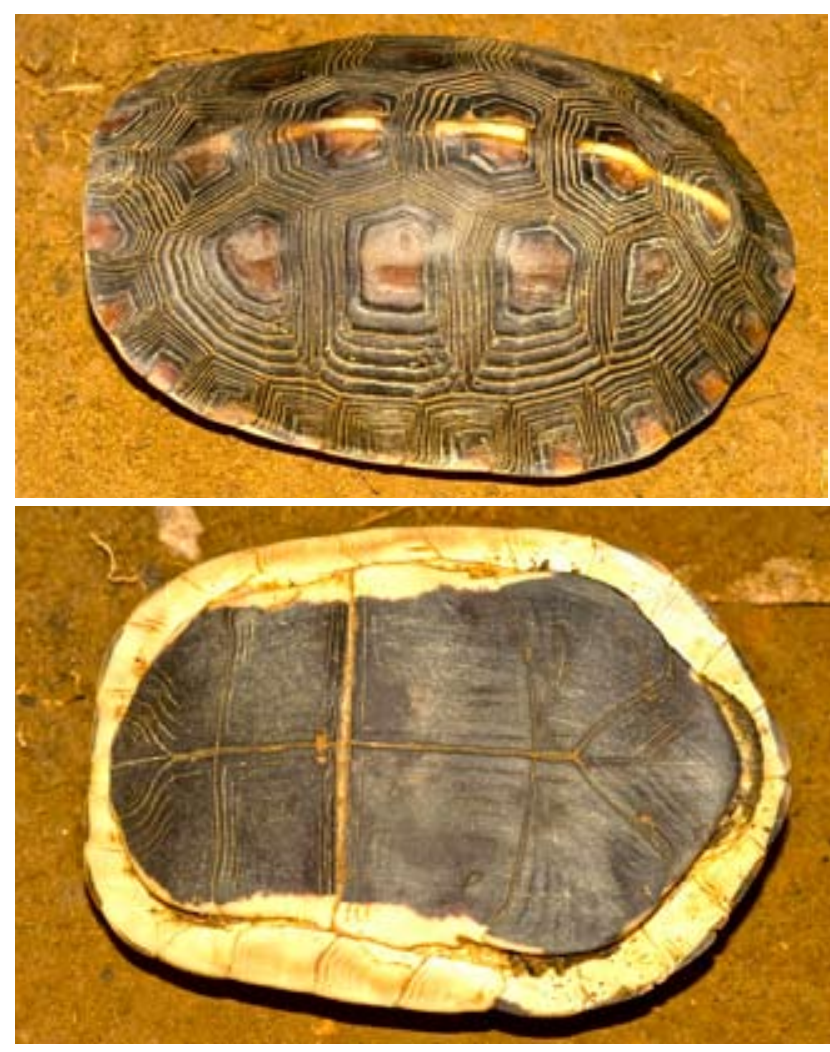

Figure 2. Cuora flavomarginata flavomarginata, adult male from Keelung, northern Taiwan. Photos by Tien-Hsi Chen.

Taxonomy. - Gray (1863), in establishing the monotypic genus Cistoclemmys, described the yellow-margined box turtle as Cistoclemmys flavomarginata on the basis of two specimens, one from Tamsuy (=Tanshui), northwestern Taiwan, and the other from continental China (Boulenger 1889). The type locality was restricted to Tamsuy by Mertens and Wermuth (1955).However, Günther(1864) synonymized the genus with Cuora Gray, 1856, and adopted the combination Cuora flavomarginata. Later, Boulenger (1889) considered Cuora to be synonymous with Cyclemys Bell, 1834, and referred to the yellow-margined box turtle as Cyclemys flavomarginata. This was followed by many subsequent authors (e.g., Stejneger 1907; Pope 1935).

However, Wermuth and Mertens (1961) resurrected the genus Cuora to accommodate most Asian box turtles, including flavomarginata. Recently Bour (1980) argued for the validity of Cistoclemmys and reassigned flavomarginata to this genus. Based on the results of cladistic analysis, chiefly using

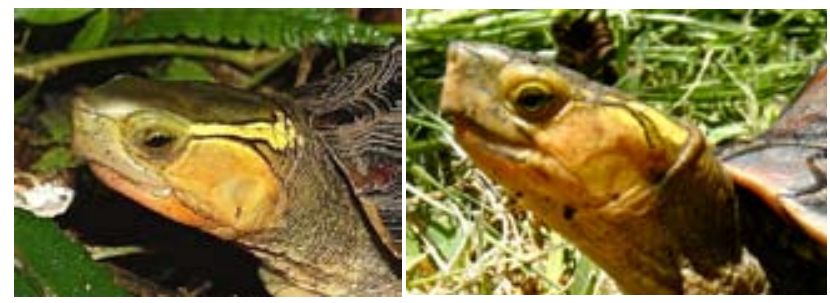

Figure 3. Left: Cuora flavomarginata flavomarginata from Keelung, northern Taiwan. Photo by Tien-Hsi Chen. Right: Cuora flavomarginata evelynae from Iriomotejima Island, southern Ryukyus. Photo by Jarmo Perälä. osteological characters, Hirayama (1984) also considered Cistoclemmys as valid and defined the genus as consisting of three species, C. flavomarginata, C. galbinifrons, and $C$. hainanensis. Since then, the validity of Cistoclemmys has been disputed (e.g., supported by Gaffney and Meylan 1988; King and Burke 1989; Ota 1991; Zhao and Adler 1993; and Yasukawa et al. 2001; but disputed by Sites et al. 1984; Ernst and Barbour 1989; Iverson 1992; Fritz and Obst 1997; and Ernst et al. 2000). Recent molecular analyses, however, invariably place the species of Cistoclemmys (as defined above), as well as the genus Pyxidea, within the Cuora clade on the resultant phylogenetic trees (Honda et al.2000; Stuart and Parham 2004; Spinks et al. 2004; Parham et al. 2004), strongly supporting synonymization of Cistoclemmys under Cuora. Recent analyses also suggested a sister group relationship of C. flavomarginata with C. yunnanensis from southern continental China (Parham et al. 2004). The latter species had been considered extinct for nearly a century (Baillie and Groombridge 1996; Hilton-Taylor 2000) until recent re-discovery (Zhou and Zhao 2004; Blanck 2005).

Hsü (1930) described a new subspecies, Cuoraflavomarginata sinensis, based upon a small sample from Tungting

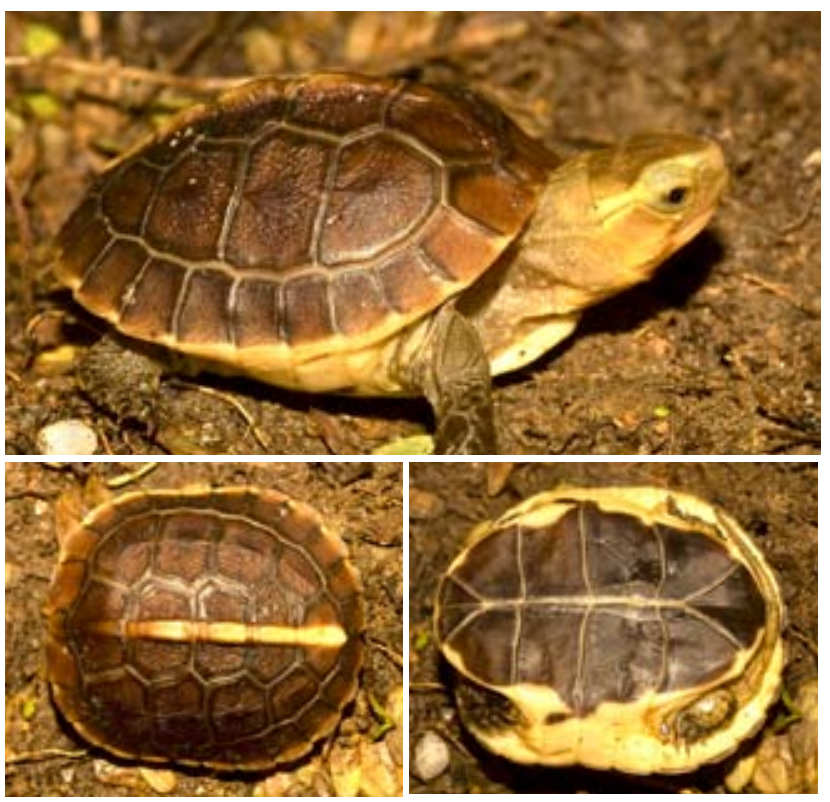

Figure 4. Hatchling Cuora flavomarginata flavomarginata from Keelung, northern Taiwan. Photos by Tien-Hsi Chen.

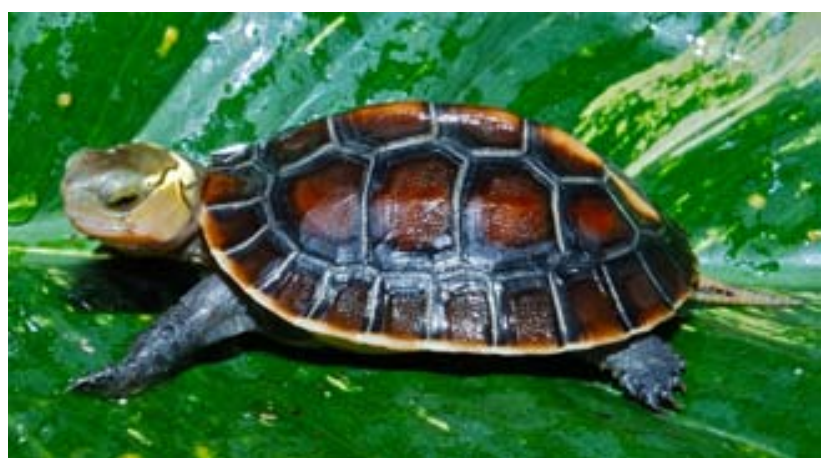

Figure 5. Hatchling Cuora flavomarginata evelynae from the Ryukyus. Photo by Hans-Dieter Philippen. 


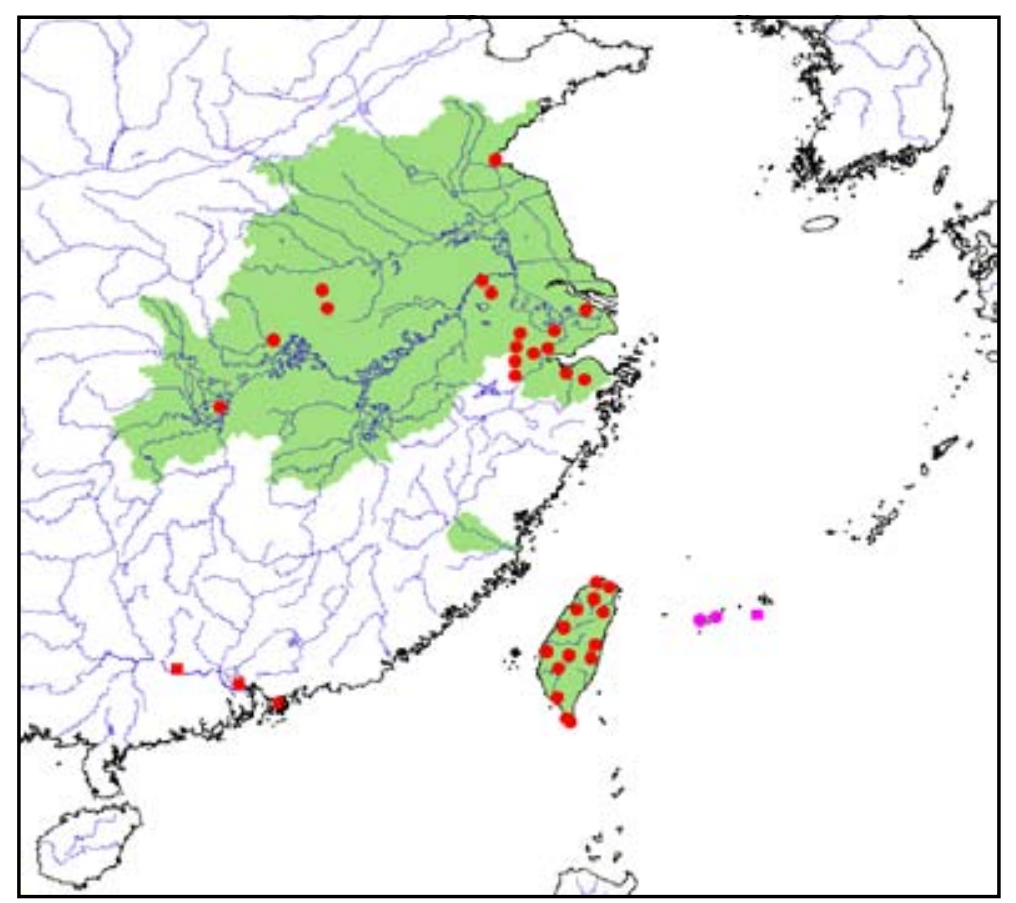

Figure 6. Distribution of Cuora flavomarginata in continental China, Taiwan, and the southern Ryukyu Archipelago of Japan. Cuoraf. flavomarginata shown with red locality points, C.f. evelynae with purple points. Points = museum and literature occurrence records based on Iverson (1992), Fong et al. (2002), plus more recent and authors' data; green shading = projected distribution based on GIS-defined hydrologic unit compartments (HUCs) constructed around verified localities and then adding HUCs that connect known point localities in the same watershed or physiographic region, and similar habitats and elevations as verified HUCs (Buhlmann et al., in press), and adjusted based on authors' data. The occurrence of $C$. $f$. flavomarginata in the Minjiang River drainage in Fujian in southeastern continental China has not been confirmed by detailed, specimen-based locality data. Localities representing assumed introduced populations in southern continental China and the Ryukyu Archipelago are indicated by color-coded squares.

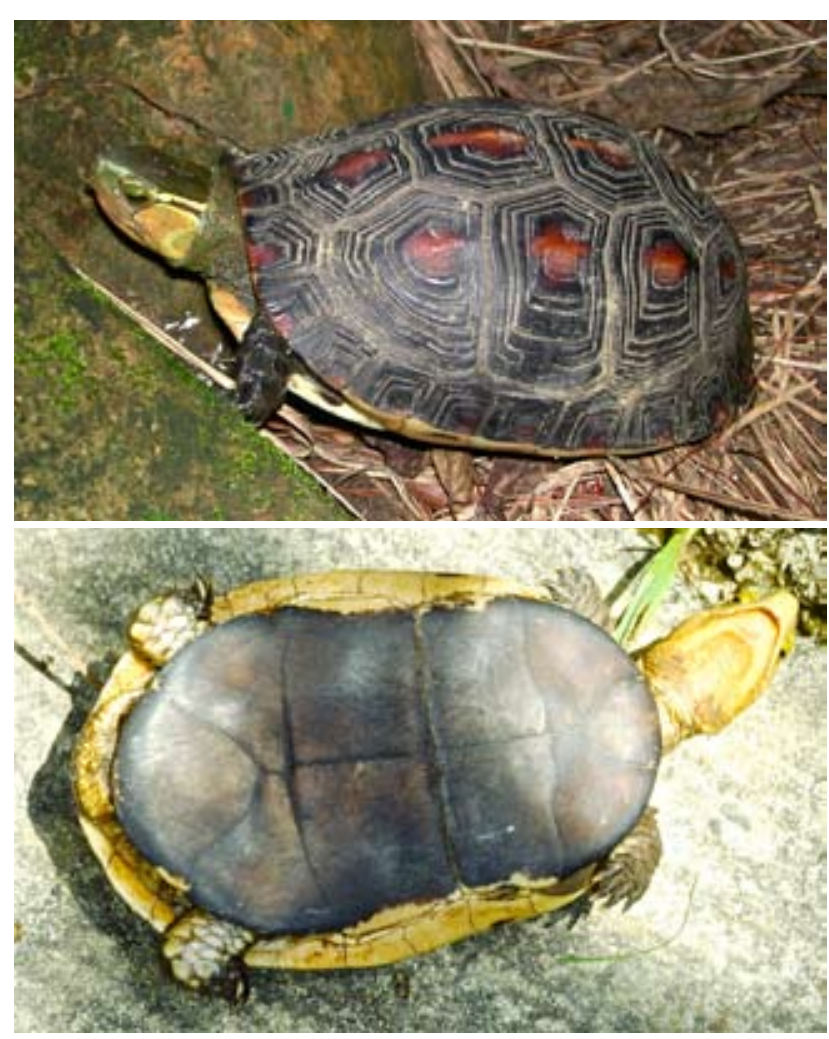

Figure 7. Cuora flavomarginata evelynae from Iriomotejima Island, southern Ryukyus. Top: adult female, photo by Iriomote Wildlife Conservation Center. Bottom: adult male, photo by Yuichirou Yasukawa.
Lake of Hunan Province, continental China. However, all diagnostic characters proposed to distinguish this subspecies from the typical form were either within the common kinds of variation to be expected in most geoemydid turtles, or were differences generally correlated with age or sex (Fang 1934; Pope 1935; Ernst and Lovich 1990).

Yeh (1961) described the box turtle Terrapene culturalia from a Neolithic archaeological midden site in continental China. However, this species was subsequently syonymized with C.flavomarginata by McCoy and Richmond (1966) on the basis of their morphological identity.

On the other hand, Ernst and Lovich (1990) made morphological comparisons among populations of continental China, Taiwan, and the Yaeyama Group of the Ryukyus, and described the Yaeyama populations as a distinct species, Cuora evelynae, chiefly on the basis of relatively large blotches of the carapace, shape of the dark plastral figure, and the relatively small number of enlarged scales on the anterior surface of the forelimbs. However, McCord and Iverson (1991) argued that, in the morphometric characters of the shell, the continental sample is the most divergent among those from the above three regions and that $C$. evelynae should be reduced to the rank of a subspecies of C. flavomarginata. Iverson (1992) regarded the species as consisting of three subspecies, C.f. flavomarginata, $C . f$. sinensis, and $C$.f.evelynae, but without providing diagnoses. Recently, Yasukawa and Ota (1999) analyzed larger samples of shell measurements than those examined by McCord 
and Iverson (1991). They found that shell morphometrics demonstrated that the Taiwanese sample had the greatest divergence and that there was an absence of substantial differentiation between the Taiwanese and continental samples. Based on these results, they tentatively synonymized C.f. sinensis with the nominotypical subspecies, while still recognizing C.f. evelynae as valid. More recently, Ernst et al. (2008) re-analyzed the morphology (including color) of Taiwanese, continental Chinese, and Ryukuys populations of the flavomarginata complex and concluded that evelynae was distinct at the species level, with continental Chinese and Taiwanese samples conspecific. However, because our latest additional analysis confirmed Yasukawa and Ota's (1999) conclusion that morphological differences between the Ryukyus and the other populations are subtle (Yasukawa and Ota, in prep.), we continue to consider evelynae as a subspecies of flavomarginata.

Description. - A relatively small geoemydid species, up to $190 \mathrm{~mm}$ carapace length (CL) in adults and ca. $35 \mathrm{~mm}$ $\mathrm{CL}$ in hatchlings. The carapace is oval, distinctly domed, and scarcely serrated marginally. The median keel is distinct, whereas lateral keels are very weak. The eighth neural and the first suprapygal are much reduced or completely lacking, and the seventh and eighth costal pairs have midline contact. The plastron is large, oval, and is not notched either anteriorly or posteriorly. A plastral hinge is present between the pectoral and abdominal scutes and between the hyo- and hypoplastral bones. The hinge is well developed, even in juveniles, enabling them to close the plastron over the four limbs and tail. In most animals, the plastral formula is Abd $><$ An $>$ Pect $>$ Gul $><$ Fem $><$ Hum, although the seam between the anals is apt to become indistinct or to disappear in adults. The entoplastron is intersected by the gular-humeral and humero-pectoral seams.

The head is relatively large. Its dorsal surface is smooth and scaleless. The upper jaw is hooked and unnotched. The triturating surfaces of the upper and lower jaws are narrow without any ridges or cusps. The anterior surfaces of the forelimbs are covered with enlarged and imbricate scales, the tips of which are rounded. Slightly smaller scales of similar shapes cover the heels of the hindlimbs. The tail is short, bearing numerous small conical scales around its base.

The skull is relatively elongate and high. The right and left premaxillae are in contact with each other anteriorly, forming a hooked beak. The cranial cavity is much narrowed anteroventrally, and the anterior end of the processus inferior parietalis is separated from the palatine and jugal by the pterygoid. The quadratojugal is usually absent, making the temporal arch incomplete, but a vestige is occasionally present. The foramen praepalatinum is excluded from the vomer. The secondary palate is not well developed. The upper and lower triturating surfaces are narrow, ridgeless, and without serration.

The ground color of the carapace is usually dark brown, but sometimes almost black. On each carapace scute, a reddish brown blotch is located around the areola. A bright or pale yellow line extends along the median keel. The plastron is totally black or dark brown, except for narrow yellow or ivory margins on the pectorals and abdomina1s (at least), sometimes on the humerals, femorals, and anals as well, but rarely on the gulars. The ground color of the head and neck varies from pale tan to olive, and a lateral broad yellow stripe, usually bordered by narrow dark lines, runs from the orbit backwards. The outside of each limb is dark olive or dark brown, and the inside is pale tan. The dorsal surface of the tail is gray with an indistinct yellowish stripe. Its ventral surface and tip are light yellow.

Adult CL does not differ significantly between the sexes, although the female tends to be larger than the male of a same age (see below). The male has a lower shell and a broader head than the female. The posterior lobe of the male plastron is slightly concave medially; whereas, the plastron of the female is perfectly flat or even slightly convex medially. The tail of the male is long and thick, with the vent located beyond the carapacial rim when the tail is extended. In the female, the tail is shorter and thinner, with the vent located within the rim. The jaw and throat are usually pale yellow, but in males they change to an orange color during the mating season (Tanaka and Sato 1983; Yasukawa, pers. obs.).

The eggshell is relatively thin, with an outer surface with numerous fine pores and weak granules (Xu et al. 1997). The karyotype is $2 \mathrm{n}=52$ (Nakamura 1949).

Distribution. - The yellow-margined box turtle is known from three distinct areas: continental China, Taiwan, and the southern Ryukyus, Japan (Nakamura and Uéno 1963; Karsen et al. 1986; Zhao 1986; Ota 1991; Toyama and Ota 1991; Iverson 1992; Zhao and Adler 1993).

In continental China, this species has been recorded broadly from the eastern and southeastern parts, including the Pearl River drainage: Henan, Sichuan, Hubei, Anhui, Jiangsu,Zhejiang, Hunan, Fujian and Guangxi Provinces, and Hong Kong (Iverson 1992; Zhao and Adler 1993; Fong et al. 2002). It is, however, very likely that the records from Hong Kong (M.W. Lau and A. Bogadek, pers. comm.) and other southeastern Chinese localities, exclusive of those in Fujian, represent translocations, and that the original continental range of the species was confined to the Minjiang, Fuchun, and Yangtze River drainages (Fong et al. 2002).

In Taiwan, this turtle is widely distributed in mesic lowland forests, although the population density is low in most localities (Chen, unpubl. data).

In Japan, distribution of this turtle was originally confined to Ishigakijima and Iriomotejima islands of the Yaeyama Group in the southern Ryukyu Archipelago (Nakamura and Uéno 1963). A number of individuals were, however, recently reported from Okinawajima and Kumejima islands of the Okinawa Group, Miyakojima Island of the Miyako Group, and Kuroshima Island of the Yeyama Group, suggesting the establishment of feral populations on these islands through translocations (Ota 1999, pers. obs.; Shiroma and Ota 2004; Maenosono and Toda 2007).

Habitat and Ecology. - Relatively little is known about the life history of the yellow-margined box turtle. Based on information from R. Swinhoe, the collector of the 
type specimens, Gray (1863) wrote that this turtle inhabits the shallow waters of ricefield ponds. Recently, Ernst and Barbour (1989) repeated these remarks. However, other recent authors have more appropriately noted that this turtle is primarily terrestrial and occurs on the forest floor (Nakamura and Uéno 1963; Takara 1969, 1979; Mao 1971; Huang et al. 1990; Matsui 1991; Wang 1991; Ota and Toyama 1996; Ota 2000b).

Results of recent preliminary surveys on Iriomotejima, southern Ryukyus, suggest that the population on this island prefers moist lowland forests rather than montane forests (Ota 1995). In continental China, however, C.flavomarginata seems to prefer more hilly environments $(200-500 \mathrm{~m}$ in altitude), and is usually found around the edges of humid forests or bushy areas not far away from water sources (Chen and Li 1979; Xia et al. 1991). Nevertheless, the turtle is rare in more aquatic habitats, such as paddy fields, ponds, and river valleys (Chen and Li 1979; Xia et al. 1983; Wang 1991). Chen and $\mathrm{Li}$ (1979), on the basis of some preliminary observations in southern Anhui, stated that the turtle often ventures farther from moist vegetation during the rainy season (June and July), but returns there after this season. During the summer (June to August), the turtle is primarily nocturnal; it usually hides itself under various objects, such as tree roots, fallen woods, and leaf litter during the day. Also, it sometimes uses rock crevices near mountain streams as shelters. During the cooler months (April and May, and September to November), the turtle becomes diurnal, being most active around noon (Wang 1991).

In Taiwan, the turtle is found within and in the vicinity of the primary and well-developed secondary forests (Chen and Lue 1999). Based on the results of mark-recapture and radio tracking, Lue and Chen (1999) reported that a northern Taiwan population exhibits distinct seasonal movements and that the patterns of the movements differ remarkably between sexes. Female $C$. flavomarginata tended to maintain higher shell surface temperature during the nesting season (May to July). In contrast, there were no obviously intersexual differences in the temperature prior to and after the nesting season (Chen and Lue 2008). Tsai (2007) also reported that the turtle stayed in bushes or litter layers and avoided open areas, such as forest gaps and areca palm plantations during the active period (March to October).

Nakamura and Uéno (1963) reported that the Japanese populations of this species are mainly herbivorous, but they also feed on small terrestrial arthropods, earthworms, land snails, and carrion, as well as acorns and berries (Takara 1969, 1979; Matsui 1991; Yasukawa, pers. obs.). Likewise, Wang (1991) reported fragments of insects and plant matter from stomachs of continental specimens. In captivity, the species feeds on various food items, such as vegetables, rice, grain, earthworms, terrestrial arthropods, land snails, tadpoles, bivalves, shrimps, small fishes, frog meat, pork, and various meat or intestines of small animals; animal food tends to be preferred over the plant food as in many other turtles (Fu, pers. obs.). In Taiwan, land snails, earthworms, fruits of Ficus septica, berries of wild taro (Alocasia odora), mulberry (Morus spp.) and some other farmed fruits have been identified in the fecal samples of this turtle (Chen, unpubl. data).

Tanaka and Sato (1983) reported on the mating behavior of C. flavomarginata on Iriomotejima Island in May. In one courtship episode, a male continuously nipped at the front edge of the carapace of a female until she withdrew her head and stopped moving. The male then released the carapace of the female, and mounted her from behind, whereupon intromission followed. Similar behavior was observed in captive specimens (Hara and Furuya 1980).

Among the few observations of the reproductive habits of this species in nature are those of Takara $(1969,1979)$, who noted that $C$. flavomarginata in the southern Ryukyus lays four to six eggs in the sandy soil near a stream or in an agricultural field between June and September, but he failed to provide citations or details.

Sexual maturity is reached at about $280 \mathrm{~g}$ in males and $400 \mathrm{~g}$ in females (Zhao 1993), or about $110 \mathrm{~mm} \mathrm{CL}$ in both sexes (Yasukawa and Ota 1999). Mating occurs from early May to late September, often in the afternoon or evening. In some instances, the male steps on the female's tail with his hind limbs before mounting, at which time the tails of the male and female are entwined (Wang 1991). In captivity, mating attempts were observed during mid-June and early October (Zhang 1986). Wang (1991) reported that the duration of mating was around ten minutes. From Wang's examination of ovaries of specimens sacrificed during different seasons, it appears that in continental populations ova start to enlarge toward the end of hibernation, and eggs are laid from late May to mid-September (usually June and July). Moreover, Wang reported that only two eggs (i.e., one in each oviduct) usually mature at once. Such a small clutch size is compensated by the production of multiple clutches; 4-8 eggs are laid per nesting season. Oviposition usually occurs in the evening or during the night. Larger females lay larger eggs, but in general they range from $40-46 \mathrm{~mm}$ in length, 20-26 mm in width, and 8.5-18.5 $\mathrm{g}$ in mass $(n=31$ : Wang 1991). Huang et al. (2000) reported slightly smaller egg numbers per season (2-5). The number of enlarged follicles reported by them is slightly greater (4-9), and this suggests the production of multiple clutches annually and/ or frequent follicular atresia. Measurements of eggs given in Huang et al. (2000) are more variable than those in Wang (1991), ranging from 39.1-50.0 mm in length, 20.2-27.5 $\mathrm{mm}$ in width, and 8.3-19.1 $\mathrm{g}$ in mass.

In Taiwan, the nesting season is known to extend from May to July. Clutch size may differ slightly between northern and southern populations, ranging from one to three in the former, reaching four in the latter. Females sometimes produce more than one clutch per nesting season (Chen and Lue 1999; Chen et al. 2000). Egg mass was 12.0-26.7 $\mathrm{g}(n=11)$, and measured from 39.6-53.4 $\mathrm{mm}$ in length $(n$ $=18)$ and from $22.6-28.0 \mathrm{~mm}$ in width $(n=18$ : Chen and Lue 1999).

Wild females are usually larger in CL and body mass than males of the same age (Chen and Xie 1988; Huang et 
al. 1990; Chen and Lue 2002) and sometimes exceed 1000 $\mathrm{g}$; whereas, males are usually smaller than $500 \mathrm{~g}$. Females continue to grow even after maturity; whereas, in males the growth rate drops remarkably after maturity (Chen and Xie 1988).

Zhang (1986) reported, on the basis of field observations in continental China, that a gravid female usually selected a quiet, moist, sandy site in an open environment, but without exposure to the direct sunlight. Using her hind-limbs, the female dug a nest-hole to a depth of ca. $5 \mathrm{~cm}$. Two eggs, 17.5 and $17.7 \mathrm{~g}$ in mass, were laid in approximately $25 \mathrm{~min}$; whereas, covering of these eggs by soil, also by using the hind-limbs, took another $30 \mathrm{~min}$. In the wild, embryonic development takes approximately 80 days, without diapause or late embryo estivation, unlike many other geoemydid species (Ewert 1991). The two hatchlings (38.2 and $38.4 \mathrm{~mm}$ in CL, 30 and $31 \mathrm{~mm}$ in carapace width $(\mathrm{CW})$, and 20 and $21 \mathrm{~mm}$ in shell height, and 12.2 and $12.7 \mathrm{~g}$ in mass) needed an additional 30-40 hours to emerge from the eggs completely. The hatchlings started to forage within 10-15 hours. In captivity, nesting females may forgo excavating egg chambers and simply lay eggs beneath leaf litter or bushes instead. Incompletely covered eggs may be subjected to predation by conspecific individuals, including their mothers. Tanaka (1984) and Tanaka and Tsuji (1985) observed remains of juvenile turtles obtained on Iriomotejima, and tentatively concluded that these were victims of predation by birds or by the wildcat Felis iriomotensis. One of us (Chen, pers. obs.) noted that, in Tawian, eggs of $C$. flavomarginata are often preyed upon by Oligodon formosanus, a colubrid snake that specializes in eating reptile eggs (Coleman et al. 1993).

In eastern continental China, hibernation usually begins in October, and activity is resumed in early April. Elevated temperatures during hibernation may stimulate activity episodes. Wang (1991) reported that the hibernaculum is usually located on a south-facing slope, under leaves, grasses, or branches (Chen and Li 1979; Wang 1991). Tsai (2007) reported that in Taiwan $C$. flavomarginata became inactive after November and stayed motionless in creek areas during the winter.

Population Status. - It is highly likely that in the Ryukyus, the Ishigakijima population is much smaller than the Iriomotejima population, because the forested area is much smaller in the former(Takara 1979). In Taiwan, the population density of this turtle appears to be much lower than in the two southern Ryukyu islands (Ota pers. obs.), although the area of the potential habitat is much more extensive. The largest populations doubtlessly occur in continental China. There, the species is reported to be in decline, largely becoming endangered as a result of over-collecting for food, the pet trade, and habitat destruction and degradation (Lau and Shi 2000; Lau et al. 2000). Nevertheless, the species remains common in Anhui and Hunan provinces, where village people sometimes keep and breed them in their yards.

Threats to Survival. - Habitat destruction caused by land development seems to be the primary threat to $C$. flavomarginata in the southern Ryukyus (Matsui 1991) and Taiwan (Chen et al. 2000).

On Iriomotejima, there are steep-sided (U-shaped) gutters along the highways running through the natural habitat of this species. Also, numerous artificial ponds, with steep concrete walls, were recently constructed within drainages running from agricultural lands to the sea, primarily for the purpose of intercepting topsoil washed off by the rainfall. Such gutters and ponds seem to function as dangerous traps for C. flavomarginata, as well as for Geoemyda japonica on Okinawajima Island (Chigira 1989; Yasukawa and Ota 2008); dead, dried-up turtles have occasionally been observed in such gutters and ponds (Ota, pers. obs.; S. Murata, pers. comm.).

On Iriomotejima, turtles of this species often venture on to the highway that passes alongside its major habitat on the island, sometimes to eat road-killed animals, and at such times they are occasionally run over themselves (Matsui 1991; Ota 1995).

In Taiwan, deforestation and habitat fragmentation in low altitude evergreen forest seem to be serious threats to this species (Chen et al. 2000). Illegal collecting for the pet and food markets in China has also impacted wild populations in Taiwan. Many cases of cross-border trades to continental China have been reported in the last few years; over 500 turtles were confiscated in 2007 alone (Chen pers. obs.).

Large numbers of turtles captured in continental China have been exported (Aoki 1990), and it is probable that such commerce constitutes a serious impact upon some continental populations (Lau and Shi 2000; Lau et al. 2000). It is also likely that, in the southern Ryukyus and Taiwan, this turtle is occasionally collected illegally as a personal pet or for sale (Chigira 1991; Matsui 1991; Kato and Ota 1993; Ota, pers. obs.), but such actions are impossible to quantify at present. In continental China, human use of these turtles for food is quite extensive also, seemingly constituting another major threat to many populations (Lau and Shi 2000; Lau et al. 2000).

Conservation Measures Taken. - Japanese populations of the yellow-margined box turtle have been designated as National Natural Monuments by the Japanese Government since 1972, and capture or trade is strictly regulated by law. Likewise, the Taiwanese Government recently started to protect this turtle as a rare and valuable species, the legislation entering into force in June 1989 as the Wildlife Conservation Act (Chen et al. 2000). These actions have presumably reduced legal exploitation of this species, but as mentioned previously, there still seems to be a certain level of illegal collecting and trade of this turtle in both countries.

The Japan Ministry of Environment also listed the yellow-margined box turtle as a Vulnerable species in the 1991 and 2000 editions of the Japanese Red Data Book (Matsui 1991; Ota 2000b). On each of Ishigakijima and Iriomotejima, habitat of the yellow-margined box turtle is partially covered by The Iriomote-Ishigaki National Park. However, due to the limited areas for strict preservation of natural habitats and wildlife in this national park, its contri- 
bution to the potential conservation of the southern Ryukyu populations of the yellow-margined box turtle appears quite limited. Additionally, Taketomi Town, the governing community of Iriomotejima, recently arranged for the placement of a gentle slope in each steep-sided artificial pond to enable trapped animals to escape, but the effectiveness of this measure remains to be seen.

In Taiwan, habitat of the yellow-margined box turtle partially overlaps a few national parks, such as Yangmingshan, Taroko, Yushan, and Kenting National Parks. This obviously contributes to conservation of turtle populations to some extent. In continental China, the turtle has been placed under provincial government regulation in Anhui, Guangdong, and Guangxi, but no detailed executive orders or regulations have been promulgated, and the species is still collected for traditional medicinal purposes and for food.

The IUCN/SSC Tortoise and FreshwaterTurtle Specialist Group (1989) did not provide an Action Plan Rating for this species, implying that it was not at that time known to need conservation action. We now conclude, based on our data, that the species deserves an APR rating of 3, indicating a species that requires some conservation action. Recent editions of the IUCN Red List listed the species as Vulnerable (Baillie and Groombridge 1996) and then as Endangered (HiltonTaylor 2000). In July 2000, the yellow-margined box turtle was added to the Appendix II of CITES together with the other species of the genus Cuora.

Conservation Measures Proposed. - The most essential effective measure for the conservation of the yellow-margined box turtle is to secure and preserve the natural forests of its habitat. It is also highly desirable to monitor illegal capture and trade in this species, especially when conducted on a commercial basis. But to develop an effective and comprehensive conservation program for this species, detailed ecological and population studies are much needed. For this purpose, mark and recapture studies and radiotelemetry monitoring, as recently attempted for a Taiwanese population (Chen and Lue 1999; Lue and Chen 1999), will be invaluable. Discrimination of native from translocated feral populations will be also crucial (Fong et al. 2002).

Captive Husbandry. - The yellow-margined box turtle is very hardy and breeds freely in captivity, and there are numerous captive breeding records. Fukada (1965) reported that a female captured on Ishigakijima, $143 \mathrm{~mm}$ in CL, laid two single-egg clutches six days apart in July. The eggs were $39.4 \times 23.8 \mathrm{~mm}$ and $13.8 \mathrm{~g}$, and $37.0 \times 23.0$ $\mathrm{mm}$ and $12.6 \mathrm{~g}$ in length, width, and mass, respectively. Hara and Furuya (1980) reported several cases of captive breeding of this turtle from the Yaeyama Group at Ueno Zoo, Tokyo. Mating behavior was observed from September to March. Females excavated a cavity in which they laid one to four eggs from January to June. These eggs (32.4-47.3 $\mathrm{x}$ 20.1-35.4 $\mathrm{mm}$ in length and width and 11.2-19.4 $\mathrm{g}$ in mass) produced hatchlings (32.4-39.9 x 23.7-33.8 mm in carapace length $\mathrm{x}$ width and 7.6-12.8 $\mathrm{g}$ in body mass) 71-81 days after being laid.
Recently, Otani (1988a) observed the nesting of this species in an open-air environment at Zoo Okinawa, Okinawajima Island, and reported that nests, $8 \mathrm{~cm}$ or less in depth, were made from 29 April to 9 June. He also stated that the clutch size ranged from 1 to $3(n=9)$, egg dimensions from 40.10-50.55 x 24.20-26.60 mm, and egg mass from $15.6-20.8 \mathrm{~g}(n=15)$, respectively. Of the $15 \mathrm{eggs}$ obtained, five hatched after 72-94 days incubation at room temperature. The hatchlings measured 32.40-37.90 CL x 29.40-32.80 carapace width $x$ 17.45-19.20 mm carapace depth and 8.4-11.4 $\mathrm{g}$ in body mass, respectively (Otani 1988b).

Huang et al. (2004) reported that $C$. flavomarginata in continental China could mature at four or five years of age in captivity; although, they usually mature six or seven years in the wild. Captive turtles showed mating in the periods from March to May and from September to October, with highest frequencies in April and October. The nesting season began in late May or early June and ended in late July. The number of eggs laid per season ranged from one to seven (usually two to four eggs), and only one clutch was usually laid per season. The activity of $C$. flavomarginata was also affected by temperature and light intensity under the captive environment; turtles could act normally with a light intensity of lower than 400 lux (Huang et al. 2007). With the increase of light intensity from 400 lux, the activity level greatly decreased. The turtles showed a maximal feeding rate under ambient temperatures between 26 and $31^{\circ} \mathrm{C}$. Hibernation began when temperatures dropped to $12^{\circ} \mathrm{C}$ (Huang et al. 2004). Hatchlings (13.2 $\mathrm{g}$ in mean body mass: $n=12$ ) emerged in August and September (Chen and Xie 1988).

Recently a number of reports have been published regarding captive husbandry and breeding of $C$. flavomarginata of unknown origins. These observations confirm the omnivorous dietary preferences and clutch size ranging from 1 to 4, but occasionally reaching 5 (Becker 1996; Shaeffer and Felsner 1997; Anonymous 2003; Schilde 2004; Klerks 2006; Gomez and Valverde 2008). Farrell (2008) stated that this species has temperature-dependent sex determination, similar to many other turtles so far examined.

Current Research. - Recently, a long-term monitoring project on the Iriomotejima population of C. flavomarginata, planned by the Japan Ministry of Environment, was launched with the full cooperation of the inhabitants of the island. In Taiwan, a population monitoring project is also in operation in a northern isolated habitat by T.-H. Chen. To detect the origins of smuggled or illegally possessed turtles, genetic surveys of confiscated individuals and of natural populations have been conducted by S.-H. Wu at National Chung Hsing University, Taichung, Taiwan.

Acknowledgments. - We thank S. Murata, M. Toyama, Y. Chigira, A. Bogadek, M.W. Lau, and T. Otani for providing information regarding various aspects of the distribution and natural history of the yellow-margined box turtle and its conservation problems. We are also much indebted to 
R. Hirayama for literature. Unpublished data and observations cited herein were collected under permission from the Japanese National Government with the courtesy of M. Toyama, K. Takehara, and Y. Chigira. We thank Iriomote Wildlife Conservation Center, Jarmo Perälä, and Hans-Dieter Philippen for photographs.

\section{LITERATURE CITED}

Anonymous. 2003. The next generation. Turtle Survival Alliance Newsletter 2003:10.

Aoki, R. 1990. Fresh water turtles of Japan. Natural History of Japan 4:60-65. (in Japanese)

BaIllie, J. AND Groombridge, B. 1996. 1996 IUCN Red List of Threatened Animals. International Union for the Conservation of Nature, Gland, Switzerland.

BeLL, T. 1834. Characters of a new genus of freshwater tortoise (Cyclemys). Proceedings of the Zoological Society of London 1834:17.

Blanck, T. 2005. Cuora yunnanensis (Boulenger, 1906), the Yunnan box turtle, rediscovered after one-hundred years? Radiata 14:10-33.

Boulenger, G.A. 1889. Catalogue of the Chelonians, Rhynchocephalians, and Crocodiles in the British Museum (Natural History). Taylor and Francis, London, 311 pp.

Bour, R. 1980. Position systématique de Geoclemys palaeannamitica Bourret, 1941 (Reptilia-Testudines-Emydidae). Amphibia-Reptilia 1:149-159.

Buhlmann, K.A., Akre, T.S., Iverson, J.B., Karapatakis, D., Mittermeier, R.A., GeOrges, A., Rhodin, A.G.J., van DiJK, P.P., And GibBons, J.W. In press. A global analysis of tortoise and freshwater turtle distributions with identification of priority conservation areas. Chelonian Conservation and Biology 8(2): in press.

Chen, B.H. And Li, B.H. 1979. Ecological materials of Cuora flavomarginata. Chinese Journal of Zoology 14:22-24. (in Chinese)

Chen, Y.G. And XIE, J.J. 1988. The measurement of growth rate of Cuora flavomarginata. Chinese Journal of Zoology 23:34-35. (in Chinese)

Chen, T.H. And Lue, K.Y. 1999. Population characteristics and egg production of the yellow-margined box turtle, Cuora flavomarginata flavomarginata, in northern Taiwan. Herpetologica 55:487-498.

ChEN, T.H. AND LuE, K.Y. 2002. Growth patterns of the yellowmargined box turtle (Cuora flavomarginata) in northern Taiwan. Journal of Herpetology 36:201-208.

ChEn, T.H. AND LuE, K.Y. 2008. Thermal preference of the yellowmargined box turtle (Cuora flavomarginata) (Testudines: Geoemydidae) inhabiting a mesic lowland forest, northern Taiwan. Amphibia-Reptilia 29:513-522.

Chen, T.H., Lin, H.C., AND Chang, H.C. 2000. Current status and utilization of chelonians in Taiwan. In: van Dijk, P.P., Stuart, B.L., and Rhodin, A.G.J. (Eds.). Asian Turtle Trade: Proceedings of a Workshop on Conservation and Trade of Freshwater Turtles and Tortoises in Asia. Chelonian Research Monographs No. 2, pp. 45-51.

Cheung, S.M. And Dudgeon, D. 2006. Quantifying the Asian turtle crisis: market surveys in southern China, 2000-2003. Aquatic Conservation: Marine and Freshwater Ecosystems 16:751-770.

ChigiRA, Y. 1989. Notes on the small vertebrates trapped in road gutters in the Yanbaru Area, the northern part of Okinawa Island,
Ryukyu Islands. World Wildlife Fund for Nature Japan, Tokyo, 33 pp. (in Japanese with English summary)

Coleman, K.J., Rothfuss, L.A., Ota, H., and Kardong, K.V. 1993. Kinematics of egg-eating by the specialized Taiwan snake, Oligodon formosanus (Boie, 1827) (Colubridae). Journal of Herpetology 27:320-327.

ERnst C.H., Altenburg, R.G.M., and Barbour, R.W. 2000. Turtles of the World (CD-ROM). Version 1.2., Springer (Editions: ETI), Berlin.

ERnst, C.H. AND Barbour, R.W. 1989. Turtles of the World. Smithsonian Institution Press, Washington, D.C., 313 pp.

ERnst, C.H. AND Lovich,J.E. 1990.Anew species of Cuora (Reptilia: Testudines: Emydidae) from the Ryukyu Islands. Proceedings of the Biological Society of Washington 103:26-34.

ERnSt, C.H., LAEMMERZAHL, A.F., AND LOVICH, J.E. 2008. A morphological review of the Cuora flavomarginata complex (Testudines: Geoemydidae). Proceedings of the Biological Society of Washington 121:391-397.

EwerT, M.A. 1991. Cold torpor, diapause, delayed hatching and aestivation in reptiles and birds. In: Deeming, D.C., and Ferguson, M.W.J. (Eds.). Egg Incubation: Its Effects on Embryonic Development in Birds and Reptiles. Cambridge: Cambridge University Press, pp. 173-191.

FANG, P.W. 1934. Notes on some chelonians of China. Sinensia 4:145-199.

FARRELL, R. 2008. Taxon management group plan for McCord's box turtle. Turtle Survival Alliance Newsletter 2008:11.

Fong, J.J., PARham, J.F., AND Fu, J. 2002. A reassessment of the distribution of Cuora flavomarginata Gray 1863 on mainland China. Russian Journal of Herpetology 9:9-14.

FRITZ, U. and OBST, F.J. 1997. Zum taxonomischen Status von Cuora galbinifrons serrata Iverson \& McCord, 1992 und Pyxidea mouhotii (Gray, 1862) (Reptilia: Testudines: Bataguridae). Zoologische Abhandlungen Staatliches Museum fur Tierkunde in Dresden 49(14):261-279.

FukadA, H. 1965. Breeding habits of some Japanese reptiles (critical review). Bulletin of the Kyoto Gakugei University, Series B 27:65-82.

GaffNey, E.S. and Meylan, P.A. 1988. A phylogeny of turtles. In: Benton, M.J. (Ed.). The Phylogeny and Classification of the Tetrapods, Vol. 1, Amphibians, Reptiles, Birds. System Assoc. Spec. Vol. 35A. Clarendon Press, Oxford, pp. 157-219.

GÓMEZ, M.R. AND VALVERDE,J. 2008. Cistoclemmys flavomarginata; keeping and breeding the yellow-margined box turtle. Reptilia 61:13-19.

GrAY, J.E. 1856. On some new species of freshwater tortoises from North America, Ceylon and Australia, in the collection of the British Museum. Proceedings of the Zoological Society of London 1855[1856](23):197-202.

Gray, J.E. 1863. Observations on the box tortoises, with the descriptions of three new Asiatic species. Proceedings of the Zoological Society of London 1863:173-177.

GÜNTHER, A. 1864. Reptiles of British India. Robert Hardwicks, London, $452 \mathrm{pp}$.

Hara, K. AND FuruYa, M. 1980. Breeding of Cuora flavomarginata in captivity. Japanese Journal of Herpetology 8:131. (Abstract in Japanese)

Hilton-Taylor, C. 2000. 2000 IUCN Red List of Threatened Species. IUCN, Gland, Switzerland.

Hirayama, R. 1984. Cladistic analysis of batagurine turtles (Batagurinae: Emydidae: Testudinoidea); a preliminary result. Studia Geologica Salmanticensia, volumen especial 1 (Studia Palaeocheloniologica I): 141-157. 
Honda, M., Yasukawa, Y., Hirayama, R., and Ota, H. 2002. Phylogenetic relationships of the Asian box turtles of the genus Cuora sensu lato (Reptilia: Bataguridae) inferred from mitochondrial DNA sequences. Zoological Science 19:1305-1312.

HorIKAwA, Y. 1934. Turtles of Taiwan. The Taiwan Jiho 181:7-16. (in Japanese)

Hsü, H.E. 1930. Preliminary note on a new variety of Cyclemys flavomarginata from China. Contributions from the Biological Laboratory of the Science Society of China, Nanjing, Zoological Series 6:1-7.

Huang, B., Chen, Y.S., And Chen, S.F. 2000. Investigation and study on fecundity of Cuora flavomarginata. Journal of Xinyang Teachers College, Natural Science Edition 13:459-461. (in Chinese with English abstract)

Huang, B., YANG, J.H., AND ZhaO, W.P. 2004. The breeding biology of Cistoclemmys flavomarginata Gray. Chinese Journal of Zoology, Beijing 39:40-44. (in Chinese with English abstract)

Huang, B., ZhaO, H.X., And Wang, J.L. 2007. Effects of light-intensity and temperature on the basic life activity of Cistoclemmys flavomarginata Gray. Journal of Xinyang Normal University, Natural Science Edition 20:313-316. (in Chinese with English abstract)

Huang, M.H., CaI, C.M., Jin, Y.L., Gu, H.Q., Zhang, S.D., Guo, H.S., AND WEI, J. 1990. Fauna of Zhejiang: Amphibia Reptilia. Hangzhou, Zhejiang Science and Technology Publishing House, 306 pp. (in Chinese).

IUCN/SSC Tortoise and Freshwater Turtle Specialist Group. 1989. Tortoises and Freshwater Turtles: An Action Plan for their Conservation. IUCN/SSC Tortoise and Freshwater Turtle Specialist Group, Gland, Switzerland, 48 pp.

IvERSON, J.B. 1992. A Revised Checklist with Distribution Maps of the Turtles of the World. Richmond, IN: Privately printed, $363 \mathrm{pp}$.

Karsen, S.J., Lau, M.W., and Bogadek, A. 1986. Hong Kong Amphibians and Reptiles. Urban Council, Hong Kong, 136 pp.

Kato, T. AND OtA, H. 1993. Endangered Wildlife of Japan. Hoikusha, Osaka, 197 pp. (in Japanese with English summary)

KING, F.W. AND BuRKE, R.L. 1989. Crocodilian, Tuatura, and Turtle Species of the World: A Taxonomic and Geographic Reference. Association of Systematics Collections, Washington, D.C., 216 pp.

KlerKs, M. 2006. Keeping and breeding the Chinese box turtle, Cuora flavomarginata (Gray, 1863). In: Artner, H., Balazs, B., and Loehr, V. (Eds.): Turtles. Proceedings: International Turtle and Tortoise Symposium Vienna 2002. Frankfurt: Edition Chimaira, pp. 13-17.

LAU, M. AND SHI, H. 2000. Conservation and trade of terrestrial and freshwater turtles and tortoises in the People's Republic of China. In: van Dijk, P.P., Stuart, B.L., and Rhodin, A.G.J. (Eds.). Asian Turtle Trade: Proceedings of a Workshop on Conservation and Trade of Freshwater Turtles and Tortoises in Asia. Chelonian Research Monographs No. 2, pp. 30-38.

Lau, M., Chan, B., Crow, P., and Ades, G. 2000. Trade and conservation of turtles and tortoises in the Hong Kong Special Administrative Region, People's Republic of China. In: van Dijk, P.P., Stuart, B.L., and Rhodin, A.G.J. (Eds.). Asian Turtle Trade: Proceedings of a Workshop on Conservation and Trade of Freshwater Turtles and Tortoises in Asia. Chelonian Research Monographs No. 2, pp. 39-44.

LI, Y., FULLER, T.K., AND W ANG, S. 1996. A survey of wildlife trade in Guangxi and Guangdong, China. TRAFFIC Bulletin 16: 9-16.

Lue, K.Y. AND Chen, T.H. 1999. Activity, movement patterns, and home range of the yellow-margined box turtle (Cuora flavomarginata) in northern Taiwan. Journal of Herpetology 33:590-600.
Maenosono, T. and Toda, M. 2007. Distributions of amphibians and terrestrial reptiles in the Ryukyu Archipelago: a review of published records. Akamata 18:28-46. (in Japanese)

MaO, S.H. 1971. Turtles of Taiwan. Commercial Press, Taipei, 128 pp.

Matsu,, M. 1991. Cuora flavomarginata flavomarginata and Geoemyda spengleri japonica. In: The Japan Environment Agency (Ed.). The Endangered Wild Animals of Japan (Vertebrates). Japan Wildlife Research Center, Tokyo, pp. 226229. (in Japanese)

McCord, W.P. AND Iverson, J.B. 1991. A new box turtle of the genus Cuora (Testudines: Emydidae) with taxonomic notes and a key to the species. Herpetologica 47:407-420.

McCoy, C.J And Richmond, N.D. 1966. The identity of the Chinese box turtle, Terrapene culturalia. Copeia 1966:886.

MCDowell, S.B. 1964. Partition of the genus Clemmys and related problems in the taxonomy of the aquatic Testudinidae. Proceedings of the Royal Society of London 143:239-279.

Mertens, R. AND Wermuth, H. 1955. Die rezenten Schildkröten Krokodile und Brückenechsen. Zoologische Jahrbücher. Abteilung für Systematik, 83:323-440.

NAKAMURA, K. 1949. A study of chromosomes in some chelonians with notes on chromosomal formula in the Chelonia. La Kromosomo 5/6:205-213. (in Japanese, with English summary)

NaKAmuRA, K. AND UÉNo, S.I. 1963. Japanese Reptiles and Amphibians in Color. Hoikusha, Osaka, 214 pp. (in Japanese)

ОтА, H. 1991. Systematics and biogeography of terrestrial reptiles of Taiwan. In: Lin, Y.S. and Chang, K.H. (Eds.). Proceedings of the First International Symposium on Wildlife Conservation, ROC. Council of Agriculture, Taipei, pp. 47-112.

ОтА, H. 1995. Semaru-hakogame (Cuora flavomarginata). In: Odate, S. (Ed.). Fundamental Data of Rare Aquatic Wildlife in Japan. II (IV). Japan Fisheries Resource Conservation Association, Tokyo, pp. 449-454. (in Japanese)

ОтА, H. 1999. Introduced amphibians and reptiles of the Ryukyu Archipelago, Japan. In: Rodda, G., Sawai, Y., Chiszar, D., and Tanaka, H. (Eds.). Problem Snake Management: The Habu and the Brown Treesnake. Cornell University Press, Ithaca, NY, pp. 439-452.

ОтА, H.2000. Semaru-hakogame (Cuoraflavomarginata evelynae). In: Environment Agency of Japan (Ed.). Threatened Wildlife of Japan - Red Data Book 2nd ed. Volume 3, Reptilia and Amphibia. Japan Wildlife Research Center, Tokyo, pp. 40-41. (in Japanese with English abstract)

OTA, H. AND ToYama, M. 1996. Semaru-hakogame (Cuora flavomarginata evelynae). In: Okinawa Prefecture Nature Conservation Division (Ed.). The Endangered Wildlife in Okinawa Prefecture-Red Data Okinawa. Okinawa: Okinawa Prefecture Nature Conservation Division, pp. 334-335. (in Japanese)

OTANI, T. 1988a. Oviposition sites and measurements of eggs of Cuora flavomarginata in captivity. Akamata 5:3-4. (in Japanese)

OTANI, T. 1988b. Hatching of Cuora flavomarginata in captivity. Akamata 5:5. (in Japanese)

PARHAM,J.F.,StuART,B.L.,Bour,R.,AND Fritz,U.2004.Evolutionary distinctiveness of the extinct Yunnan box turtle revealed by DNA from an old museum specimen. Proceedings of the Royal Society Series B: Biology Letters 271(1556[S6]):391-394.

Pope, C.H. 1935. Natural History of Central Asia, Vol. 10. The Reptiles of China. American Museum of Natural History, New York, 604 pp.

SchILDE, M. 2004; Asiatische Sumpfschildkröten; die Familie 
Geoemydidae in Südostasien, China und Japan. Natur und Tier Verlag, Munster, $192 \mathrm{pp}$.

ShaefFer, G. and Felsner, H. 1997. Haltung und Nachzucht der Gelbrand-Scharnierschildkröte Cuora flavomarginata. Emys 4(4):5-12.

Shiroma, T. AND Ota, H. 2004. Distribution and status of alien amphibians and reptiles in the Miyako Islands, Ryukyu Archipelago. Bulletin of the Hirara City Museum 9:57-66. (in Japanese with English abstract)

Sites, J.W., JR., Bickham, J.W., Pytel, B.A., Greenbaum, I.F., AND BATES, B.B. 1984. Biochemical characters and the reconstruction of turtle phylogenies: relationships among batagurine genera. Systematic Zoology 33:137-158.

SPINKS, P.Q., ShafFer, H.B., IVERSON, J.B., AND McCoRd, W.P. 2004. Phylogenetic hypotheses for the turtle family Geoemydidae. Molecular Phylogenetics and Evolution 32:164-182.

STEJNEGER, L.H. 1907. Herpetology of Japan and adjacent territory. Bulletin of the United States National Museum 58:1-577.

StUART, B.L. AND PARHAM, J.F. 2004. Molecular phylogeny of the critically endangered Indochinese box turtle Cuora galbinifrons. Molecular Phylogenetics and Evolution 31:164-177.

TAKARA, T. 1969. Life and Nature of Ryukyus. Ryukyu BunkyoTosho, Naha, 206 pp. (in Japanese)

TAKARA, T. 1979. Cuora flavomarginata flavomarginata and Geoemyda spengleri japonica. In: Nature Conservation Society of Japan (Ed.). A Survey Report on the Distributions of Wild Animals of Japan. Amphibians and Reptiles. Nature Conservation Society of Japan, Tokyo, pp. 109-114. (in Japanese)

TanaKa, S. 1984. Possibility of the predation of juvenile box turtle, Cistoclemmys flavomarginata by birds. Akamata 2:5. (in Japanese)

TanaKa, S. And Sato, F. 1983. A field observation of the mating behavior of Cuora flavomarginata flavomarginata. Biological Magazine, Okinawa 21:75-76. (in Japanese)

TANAKA, S. AND Tsus, M. 1985. Possible predation of a juvenile box turtle Cuora flavomarginata flavomarginata by the Iriomote wildcat Mayailurus iriomotensis. Akamata 3:1-3. (in Japanese with English abstract)

Toyama, M. 1985. The herpetology of the Ryukyu archipelago. In: World Wildlife Fund, Japan Scientific Committee (Ed.). Conservation of the Nansei Shoto, Part 2. World Wildlife Fund, Tokyo, pp. 54-152. (in Japanese)

Toyama,M.ANDOTA,H. 1991.Amphibians and reptiles of the Ryukyu Islands. In: World Wildlife Fund, Japan (Ed.). Study of Essential Factors for Preservation of Wildlife in Nansei Islands. The Japan Environment Agency, Nature Conservation Department, Tokyo, pp. 229-229. (in Japanese with English summary)

TsAI, C.F. 2007. Daily activity patterns and home range of Cuora flavomarginata in a monsoon forest in southern Taiwan. Masters Thesis, Institute of Biodiversity, National Cheng Kung University, Tainan, Taiwan.

W ANG, Y. 1991. Cistoclemmys flavomarginata. In: Chen, B. (Ed.). The Amphibiam [sic] and Reptilian Fauna of Anhui. Hefei: Anhui Publishing House of Science and Technology, pp. 183-187. (in Chinese)

Wermuth, H. and Mertens, R. 1961. Schildkröten, Krokodile, Brüchenechsen. G. Fischer, Jena, 422 pp.

WinK, M., GuIKING, D., AND FRITZ, U. 2001. Molecular evidence for hybrid origins of Mauremys iversoni Pritchard and McCord, 1991, and Mauremys pritchardi McCord, 1997 (Reptilia: Testudines: Bataguridae). Zoologische Abhandlungen Staatliches Museum fur Tierkunde in Dresden 51:41-49.

Wu, P., ZHou, K., AND Y ANG, Q. 1998. Evolution of hinged turtles in Bataguridae inferred from sequences of $12 \mathrm{~S}$ rRNA gene. Chinese Journal of Applied and Environmental Biology 4:374-378. (in Chinese with English abstract)

Wu, X.B., Nie, L.W., Yu, L., W ANG, Y.H., AND MeI, B. 1997. Observations on the egg-shell of Cuora aurocapitata and Cistoclemmys flavomarginata. In: Zhao, E. (Ed.). Chinese Chelonian Research. Chinese Society for the Study of Amphibians and Reptiles, Herpetological Series No. 9, Sichuan Journal of Zoology 15 (Suppl.):121-126.

YASUKAWA, Y. AND OTA, H. 1999. Geographic variation and biogeography of the geoemydine turtles (Testudines: Bataguridae) of the Ryukyu Archipelago, Japan. In: Ota, H. (Ed.). Tropical Island Herpetofauna: Origin, Current Diversity and Conservation. Elsevier, Amsterdam, pp. 271-297.

YasuKawa, Y. and Ota, H. 2008. Geoemyda japonica Fan 1931 - Ryukyu black-breasted leaf turtle, Okinawa black-breasted leaf turtle. In: Rhodin, A.G.J., Pritchard, P.C.H., van Dijk, P.P., Saumure, R.A., Buhlmann, K.A., and Iverson, J.B. (Eds.). Conservation Biology of Freshwater Turtles and Tortoises: A Compilation Project of the IUCN/SSC Tortoise and Freshwater Turtle Specialist Group. Chelonian Research Monographs No. 5, pp.002.1-002.6,doi:10.3854/crm.5.002.japonica.v1.2008,http:// www.iucn-tftsg.org/cbftt.

Yasukawa, Y., Hirayama, R., and Hikida, T. 2001. Phylogenetic relationships of geoemydine turtles (Reptilia: Bataguridae). Current Herpetology 20:105-133.

YeH, H.K. 1961. The first discovery of a box-turtle in China. Vertebrata Palasiatica 5:58-64.

XIA, J.Y., Chen, L., WANG, Y.Q., And Chen, B.H. 1983. Comparative studies and observations on habits of turtles in southern Anhui. Sichuan Journal of Zoology 2:30-34. (in Chinese)

ZHANG,H. 1986. Studies on breeding Cuora flavomarginata. Chinese Journal of Zoology, Beijing 21:11-13. (in Chinese)

Zнао, E. 1986. A revised catalogue of Chinese tortoises. Acta Herpetologica Sinica 5:145-148.

ZhaO, E. And Adler, K. 1993. Herpetology of China, Contribution of Herpetology, Vol. 10. Society for the Study of Amphibians and Reptiles, Oxford, 520 pp.

Zнао, P. 1993. Urogenital system of Cuora flavomarginata. Chinese Journal of Zoology 28:31-34. (in Chinese)

Zhou, T. and Zhao, E.M. 2004. On the occurrence of living Cuora yunnanensis since fifty-eight years, and its description. Sichuan Journal of Zoology 23(4):325-327.

\section{Citation Format for this Account:}

Ota, H., Yasukawa, Y., Fu, J., and Chen, T.H. 2009. Cuora flavomarginata (Gray 1863) - yellow-margined box turtle. In: Rhodin, A.G.J., Pritchard, P.C.H., van Dijk, P.P., Saumure, R.A., Buhlmann, K.A., Iverson, J.B., and Mittermeier, R.A. (Eds.). Conservation Biology of Freshwater Turtles and Tortoises: A Compilation Project of the IUCN/SSC Tortoise and Freshwater Turtle Specialist Group. Chelonian Research Monographs No. 5, pp. 035.1-035.10, doi:10.3854/crm.5.035.flavomarginata. v1.2009, http://www.iucn-tftsg.org/cbftt/. 